\title{
Analisis Strategi Pemasaran Proyek Perumahan Permata Alam di Jombang
}

\section{Analysis of Marketing Strategy for Permata Alam Housing Project in Jombang}

\author{
Totok Yulianto ${ }^{1}$, Laela A kmalinda Assoraya ${ }^{2}$ \\ ${ }^{1}$ Program Studi Teknik Sipil, Fakultas Teknik, Universitas Hasyim Asy'ari Tebuireng, Jombang, 61411, Indonesia \\ Email: totokyulianto36@gmail.com \\ ${ }^{2}$ Program Studi Teknik Sipil, Fakultas Teknik, Universitas Hasyim Asy'ari Tebuireng, Jombang, 61411, Indonesia \\ Email: laelaakmalinda150997@gmail.com
}

\begin{abstract}
Abstrak
Kebutuhan perumahan yang semakin meningkat menyebabkan banyaknya proyek perumahan di Kabupaten Jombang. Ketatnya persaingan proyek pembangunan perumahan mengharuskan pengembang memiliki strategi yang tepat untuk memasarkan perumahan. Perumahan Permata Alam berlokasi di Kabupaten Jombang, Jawa timur dibangun pada area lahan seluas tanah $7.410 \mathrm{~m}^{2}$. Metode SWOT meliputi nilai Strenght (kekuatan), Weakness (kelemahan), Opportunities (peluang), Threats (ancaman) dengan perhitungan software SPSS digunakan untuk menganalisis strategi pemasaran proyek perumahan Permata Alam. Hasil analisis pembangunan perumahan permata alam bersubsidi tersebut dapat dilihat dari nilai perhitungan bobot kekuatan (strength), bobot kelemahan (weaknees), bobot peluang (opportunity), bobot ancaman (threats), rating kuestioner, hasil nilai matriks IFAS (Internal Factor Analysis Summary) total 5,47 dan hasil nilai matriks EFAS (Eksternal Factor Analysis Summary) denga total 6,02, setelah itu dicari selisih skor dari faktor internal yaitu 1 dan hasil skor dari faktor eksternal adalah 0,40. Kemudian dijadikan diagram layang ketemu kuadrant 1 dengan hasil strategi agresif (positif-positif) yaitu pembangunan proyek perumahan subsidi bisa dilakukan dengan hasil yang menguntungkan.
\end{abstract}

Kata Kunci: Perumahan; SWOT; strategi; pemasaran; IE

\begin{abstract}
The increasing need for housing has led to the number of housing projects in the Jombang Regency. The intense competition for housing development projects requires that developers have the right strategy to market housing. Permata Alam Housing, located in Jombang Regency, East Java, is built on a land area of 7,410 m2. The SWOT method includes the value of Strength (strength), Weakness (weakness), Opportunities (opportunities), Threats (threats) with the calculation of SPSS software used to analyze the marketing strategy of the Permata Alam housing project. The results of the analysis of the subsidized natural gem housing development can be seen from the calculation value of the strength (strength), the weight of the weakness (weakness), the weight of opportunities (threats), the rating of the questionnaire, the results of the IFAS matrix value (Internal Factor Analysis Summary). a total of 5.47 and the results of the EFAS (External Factor Analysis Summary) matrix value with a total of 6.02, after which the difference in the score of internal factors is 1 and the score results from external factors are 0.40. Then it is used as a flyover diagram to meet quadrant 1 with the results of an aggressive strategy (positives-positives), namely the construction of subsidized housing projects can be carried out with profitable results.
\end{abstract}

Keywords: Housing; SWOT; marketing; strategy; IE 


\section{PEDAHULUAN}

Perumahan merupakan suatu kelompok rumah yang berfungsi sebagai tempat tinggal yang telah dilengkapi dengan prasarana lingkungan seperti, ketersediaan listrik, pembuangan sampah, air bersih, jalan dan lainnya yang berfungsi sebagaimana mestinya. Rumah adalah sebuah struktur yang terdiri dari ruangan halaman dan area sekitar yang dipakai sebagai tempat tinggal keluarga (UU RI No. 4 Tahun 1992).

Dalam analisa Yulita Veranda Usman, dan Wiwin Yaren (2015) tentang "Analisis Strategi Pemasaran Perumahan Bekasi Timur Regensi 3" menyatakan bahwa pada masa sekarang perumahan di tanah air terbilang sangat pesat pertumbuhannya dan juga didorong oleh meningkatnya permintaan masyarakat akan perumahan yang sesuai dengan tingkat kebutuhannya.

Maka proyek perumahan harus dicari strategi pemasaran untuk dianalisis dengan aspek teknis.

Agar bertujuan untuk memberikan garis besar yang berkaitan dengan wujud fisik proyek.

Investasi perumahan dan properti masih menjadi pilihan sebagaian orang, banyak menganggap investasi pada bidang properti sebagai salah satu cara yang baik untuk dikembangkan uangnya.

Proyek perumahan dibangun pada area seluas tanah $7.410 \mathrm{~m}^{2}$.

Pada proyek perumahan ini dicari hasil dari faktor internal dan faktor eksternal dengan menggunakan metode SWOT yang digunakan untuk menentukan pokok terpenting dari proyek perumahan ini seperti kekuatan, kelemahan, peluang, dan ancaman.

\section{TINJAUAN PUSTAKA \\ Aspek Teknis}

Aspek teknik adalah aspek yang berhubungan tentang teknis proyek contohnya lokasi, fasilitas, tinggi bangunan, luas bangunan, penataan ruang, dan keunggulan perumahan (Soeharto,1999).

\section{Statistik}

Menurut Prof. Dr. Sudjana,M.A., M.Sc statistik adalah suatu pengetahuan yang berkaitan dengan metode untuk pengumpulan data, pengolahan data, analisis, serta menarik kesimpulan berdasarkan kumpulan data dan analisis yang dilaksanakan.

\section{Uji Validitas}

Uji validitas adalah untuk mengetahui tingkat kevalidan pada kuesioner yang telah digunakan dalam pengumpulan data dengan cara mengkorelasikan setiap skor variabel jawaban responden dengan total skor masing-masing variabel.

\section{Uji Reliabilitas}

Uji reliabitas adalah ukuran konsistensi skor yang dicapai oleh orang yang sama tetapi pada kesempatan yang berbeda atau dengan kata lain alat ukur mempunyai hasil yang konsisten apabila digunakan untuk berkali-kali pada waktu yang berbeda. (Djaali dan Pudji, 2008)

\section{Metode SWOT}

Analisis SWOT adalah alat yang digunakan oleh perusahaan untuk mengetahui faktor-faktor internal maupun eksternal perusahaan.

\section{Internal}

Matriks IFAS (Internal Factor Analysis Summary)

Kekuatan (Strength) adalah kemampuan yang mempunyai nilai lebih perusahaan dibandingkan kemampuan pesaing.

Kelemahan (Weakness) adalah faktor yang bisa mengurangi kemampuan perusahaan, hal ini bisa diminimalisir agar tidak menggangu perusahaan.

\section{Ekstrenal}

Matriks EFAS (Eksternal Factor Analysis Summary)

Peluang (Oppurtunity) adalah kesempatankesempatan yang menghasilkan keuntungan bagi perusahaan.

Ancaman (Threat) adalah sesuatu yang sangat mungkin terjadi atas perusahaan dan berpotensi merugikan bagi perusahaan.

\section{METODE}

Adapun diagram alir pada penelitian ini adalah sebagai berikut: 


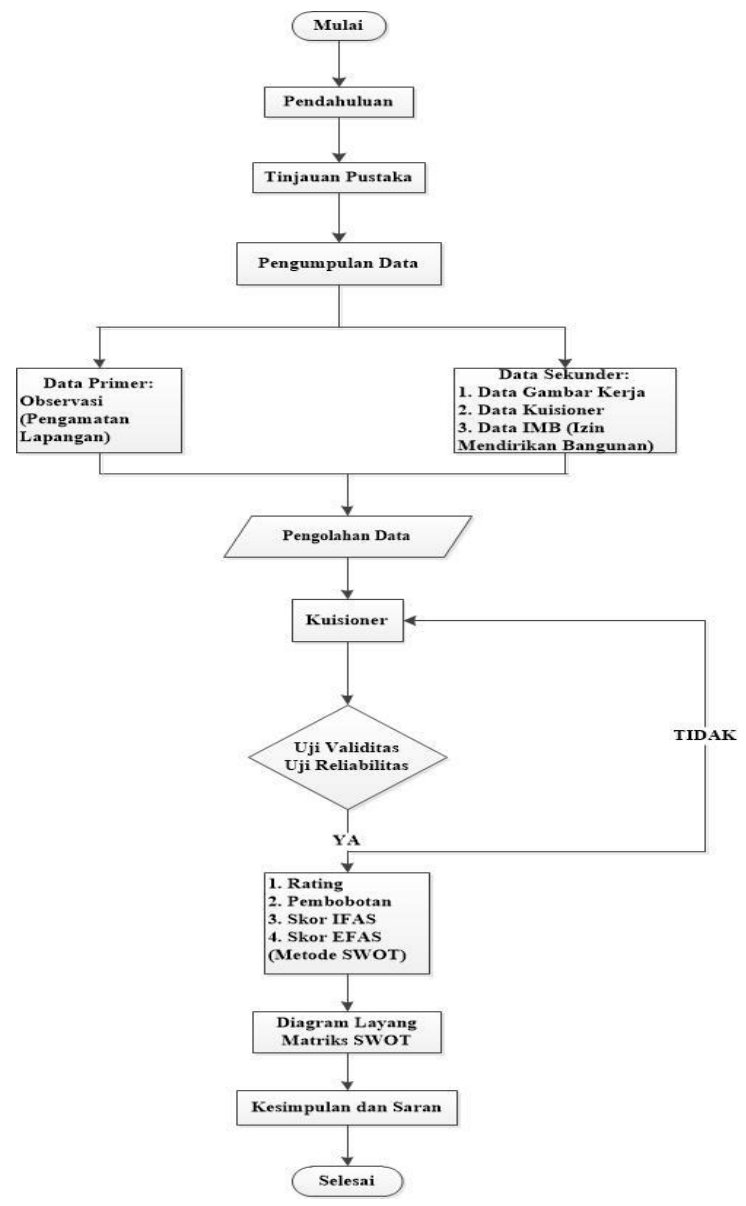

Gambar 1. Diagram Alir Penelitian (Sumber: Analisis Penelitian 2020)

\section{HASIL DAN PEMBAHASAN}

\section{Aspek Teknis}

Hasil kegiatan menggunakan analisis SWOT meneliti meneliti berbagai faktor dalam strategi yang berkaitan dengan tujuan kegiatan yang akan dilaksanakan. Strategi pemasaran perumahan dilakukan dengan cara menganalisis faktor internal dan faktor eksternal.

\section{Uji Validitas}

Uji validitas yaitu untuk menentukan apakah data responden dinyatakan valid atau tidak valid. Uji validitas dengan jumlah sampel 36 responden, nilai rtabel sebesar 0,329. Dilihat dari rtabel dengan signifikansi 5\%, maka rtabel adalah 0,329.
Tabel 1. Rangkuman Hasil Uji Validitas

\begin{tabular}{crll}
\hline $\begin{array}{l}\text { No soal } \\
\text { pertanyaan }\end{array}$ & \multicolumn{1}{l}{ rhitung } & \multicolumn{1}{l}{ rtabel } & Keterangan \\
\hline S1 & 0,532 & 0,329 & Valid \\
\hline S2 & 0,441 & 0,329 & Valid \\
\hline S3 & 0,439 & 0,329 & Valid \\
\hline S4 & 0,412 & 0,329 & Valid \\
\hline S5 & 0,649 & 0,329 & Valid \\
\hline S6 & 0,343 & 0,329 & Valid \\
\hline S7 & 0,370 & 0,329 & Valid \\
\hline W1 & 0,401 & 0,329 & Valid \\
\hline W2 & 0,390 & 0,329 & Valid \\
\hline W3 & 0,437 & 0,329 & Valid \\
\hline W4 & $-0,200$ & 0,329 & Tidak Valid \\
\hline W5 & $-0,184$ & 0,329 & Tidak Valid \\
\hline W6 & 0,485 & 0,329 & Valid \\
\hline O1 & 0,641 & 0,329 & Valid \\
\hline O2 & 0,611 & 0,329 & Valid \\
\hline O3 & 0,558 & 0,329 & Valid \\
\hline O4 & 0,362 & 0,329 & Valid \\
\hline O5 & 0,599 & 0,329 & Valid \\
\hline T1 & 0,438 & 0,329 & Valid \\
\hline T2 & 0,455 & 0,329 & Valid \\
\hline T3 & 0,425 & 0,329 & Valid \\
\hline T4 & 0,183 & 0,329 & Tidak Valid \\
\hline T5 & 0,396 & 0,329 & Valid \\
\hline & S & Hasil Analisis & 2020) \\
\hline
\end{tabular}

(Sumber: Hasil Analisis 2020)

Dilihat dari tabel 1 ada beberapa pernyataan yang tidak valid, yaitu nomer $\mathrm{W}_{4}, \mathrm{~W}_{5}$, dan $\mathrm{T}_{4}$. Maka, 3 pertanyaan tersebut tidak digunakan lagi ke perhitungan selanjutnya karena dinyatakan tidak valid.

\section{Uji Reliabilitas}

Uji reliabilitas yaitu hasil pengukuran yang dapat dipercaya dengan menggunakan software SPSS seperti tabel berikut:

Tabel 2. Uji Reliabilitas

\begin{tabular}{c}
\hline \multicolumn{2}{c}{ Reliability Statistics } \\
\hline Cronbach's Alpha N of Items \\
\hline ,635
\end{tabular}

Pada tabel 2 dapat disimpulkan bahwa uji reliabilitas diperoleh nilai Cronbach's alpha sebesar ,635 atau 63,5\%. Sedangkan dari (Nunnally.1960), apabila nilai cronbach's alpha lebih besar dari $0,6 \%$, maka kuesioner tersebut dinyatakan reliabel. Sehingga, tabel diatas menunjukkan bahwa nilai cronbach's alpha sebesar $63,5 \%>0,6 \%$ dinyatakan reliabel.

Proteksi/Juni 2021 Volume 3 No. 1 


\section{Data Kuesioner}

Kuesioner adalah teknik pengumpulan data dengan mengajukan pertanyaan untuk dijawab oleh responden. Pada data kuesioner membuat sebuah pertanyaan untuk responden sebanyak 23 pertanyaan dan disebar kepada responden sebanyak 36 orang dengan rata-rata orang yang mempunyai penghasilan perbulan.

\section{Rating}

Rating adalah penilaian yang dilakukan oleh pihak tertentu terhadap suatu hal ataupun pertanyaan. Untuk mengetahui berapa rating yang didapat harus menggunakan data kuesioner, tabel hasil rating dapat dilihat sebagai berikut:

Tabel 3. Rating Faktor Internal

\begin{tabular}{|c|c|c|c|c|c|}
\hline \multicolumn{6}{|c|}{ Rating Faktor Internal } \\
\hline \multirow{2}{*}{ Kode } & \multirow{2}{*}{ Kekuatan } & \multicolumn{4}{|c|}{ Rating } \\
\hline & & 1 & 2 & 3 & 4 \\
\hline S1 & $\begin{array}{l}\text { Produk perumahan Permata Alam } \\
\text { bersubsidi dengan standart FLPP } \\
\text { ( faliditas likuiditas pembiayaan } \\
\text { perumahan) }\end{array}$ & 0 & 2 & 19 & 15 \\
\hline $\mathrm{S} 2$ & $\begin{array}{l}\text { Lokasi dekat dengan pasar } \\
\text { tradisional } \\
\text { kurang lebih } 1,3 \mathrm{~km}\end{array}$ & 0 & 1 & 18 & 17 \\
\hline S3 & $\begin{array}{l}\text { Lokasi dekat dengan yayasan } \\
\text { pendidikan } \\
\text { (Pondok Pesantren dan Sekolah) }\end{array}$ & 0 & 3 & 11 & 22 \\
\hline S4 & $\begin{array}{l}\text { Bangunan layak huni dengan } \\
\text { standar } \\
\text { ( faliditas likuiditas pembiayaan } \\
\text { perumahan) }\end{array}$ & 0 & 7 & 14 & 15 \\
\hline S5 & $\begin{array}{l}\text { Tipe bangunan dengan luas } \\
\text { bangunan } \\
\text { (diatas standar minimal } 21 \mathrm{~m} 2 \text { ) }\end{array}$ & 0 & 11 & 19 & 6 \\
\hline S6 & $\begin{array}{l}\text { Petak lahan dengan luas tanah } 63 \\
\mathrm{~m} 2 \\
\text { ( diatas standar minimal } 60 \mathrm{~m} 2 \text { ) }\end{array}$ & 0 & 13 & 16 & 7 \\
\hline S7 & $\begin{array}{l}\text { Luas jalan fasum perumahan } 7.5 \\
\mathrm{~m} 2 \\
(\text { diatas standar minimal } 6 \mathrm{~m} 2)\end{array}$ & 0 & 10 & 18 & 8 \\
\hline Kode & Kelemahan & & & & \\
\hline W1 & Lokasi dekat dengan pemakaman & 3 & 14 & 13 & 6 \\
\hline W2 & $\begin{array}{l}\text { Lokasi tidak berada di Nol jalan } \\
\text { pengelolaan pemerintah }\end{array}$ & 3 & 17 & 12 & 4 \\
\hline W3 & $\begin{array}{lll}\text { Lokasi lahan setara dengan } \\
\text { elevasi jalan }\end{array}$ & 5 & 13 & 12 & 6 \\
\hline W4 & $\begin{array}{l}\text { Mutu bahan usuk dari kayu yang } \\
\text { mudah terbakar }\end{array}$ & 5 & 12 & 12 & 7 \\
\hline W5 & $\begin{array}{l}\text { Tidak ada dinding pagar } \\
\text { perumahan }\end{array}$ & 2 & 20 & 12 & 2 \\
\hline W6 & $\begin{array}{l}\text { Minimnya penerangan pada akses } \\
\text { jalan masuk perumahan }\end{array}$ & 1 & 21 & 14 & 0 \\
\hline
\end{tabular}

(Sumber: Hasil Analisis 2020)
Pada tabel 3 adalah data jumlah responden yang mengisi skala nilai rating pada masing-masing pernyataan untuk faktor internal yaitu kekuatan dan kelemahan.

Tabel 4. Rating Faktor Eksternal

\begin{tabular}{|c|c|c|c|c|c|}
\hline \multicolumn{6}{|c|}{ Rating Faktor Eksternal } \\
\hline \multirow[t]{2}{*}{ Kode } & \multirow[t]{2}{*}{ Peluang } & \multicolumn{4}{|c|}{ Rating } \\
\hline & & \multicolumn{2}{|c|}{1} & 2 & \\
\hline $\mathrm{O} 1$ & $\begin{array}{l}\text { Permintaan penyediaan } \\
\text { perumahan } \\
\text { subsidi masih tinggi }\end{array}$ & 1 & 8 & 18 & 9 \\
\hline $\mathrm{O} 2$ & $\begin{array}{l}\text { Tingkat bunga KPR yang } \\
\text { rendah dan tetap }\end{array}$ & 0 & 7 & 10 & 19 \\
\hline $\mathrm{O} 3$ & $\begin{array}{ll}\begin{array}{l}\text { Penyediaan } \\
\text { pemakaman }\end{array} & \text { lahan } \\
\end{array}$ & 0 & 9 & 22 & 5 \\
\hline $\mathrm{O} 4$ & $\begin{array}{l}\text { Tingkat daya beli } \\
\text { masyarakat } \\
\text { perumahan bersubsidi }\end{array}$ & 0 & 14 & 16 & 6 \\
\hline O5 & $\begin{array}{l}\text { Adanya nilai tambah tiap } \\
\text { tahun } \\
\text { terhadap harga jual lahan }\end{array}$ & 0 & 12 & 15 & 9 \\
\hline Kode & Ancaman & & Rating & & \\
\hline $\mathrm{T} 1$ & $\begin{array}{l}\text { Kenaikan harga jual } \\
\text { perumahan } \\
\text { subsidi tiap tahun }\end{array}$ & 5 & 10 & 13 & 8 \\
\hline $\mathrm{T} 2$ & $\begin{array}{l}\text { Tidak ada bangunan } \\
\text { komersil } \\
\text { dalam bentuk ruko }\end{array}$ & 1 & 14 & 16 & 5 \\
\hline T3 & $\begin{array}{l}\text { Banyaknya bermunculan } \\
\text { penyediaan } \\
\text { kavling dan perumahan } \\
\text { non subsidi }\end{array}$ & 1 & 13 & 14 & 8 \\
\hline T4 & $\begin{array}{l}\text { Adanya isu pencemaran } \\
\text { lingkungan }\end{array}$ & 9 & 11 & 5 & 11 \\
\hline T5 & $\begin{array}{l}\text { Kenaikan harga material } \\
\text { dan upah }\end{array}$ & 3 & 7 & 20 & 6 \\
\hline \multicolumn{6}{|c|}{ (sumber: Hasil Analisis 2020) } \\
\hline \multirow{2}{*}{\multicolumn{6}{|c|}{$\begin{array}{l}\text { Pada tabel } 4 \text { merupakan hasil dari jumlah data } \\
\text { kuesioner yang mengisi skala nilai rating pada } \\
\text { masing-masing pertanyaan yaitu peluang dan } \\
\text { ancaman untuk faktor eksternal. } \\
\text { Tabel 5. Perhitungan Bobot Faktor Internal }\end{array}$}} \\
\hline & & & & & \\
\hline \multicolumn{6}{|c|}{ Bobot Faktor Internal } \\
\hline Kode & Kekuatan & $\begin{array}{l}\text { umla } \\
\text { kues }\end{array}$ & $\begin{array}{l}\text { data } \\
\text { ner }\end{array}$ & Bo & \\
\hline $\mathrm{S} 1$ & $\begin{array}{l}\text { Produk perumahan } \\
\text { Permata Alam } \\
\text { bersubsidi dengan } \\
\text { standart FLPP } \\
\text { ( faliditas likuiditas } \\
\text { pembiayaan perumahan) }\end{array}$ & & & & \\
\hline
\end{tabular}

Proteksi/Juni 2021 Volume 3 No. 1 


\begin{tabular}{|c|c|c|c|}
\hline S2 & $\begin{array}{l}\text { Lokasi dekat dengan } \\
\text { pasar tradisional } \\
\text { kurang lebih } 1,3 \mathrm{~km}\end{array}$ & 124 & 0,16 \\
\hline S3 & $\begin{array}{l}\text { Lokasi dekat dengan } \\
\text { yayasan pendidikan } \\
\text { (Pondok Pesantren dan } \\
\text { Sekolah) }\end{array}$ & 127 & 0,16 \\
\hline $\mathrm{S} 4$ & $\begin{array}{l}\text { Bangunan layak huni } \\
\text { dengan standar FLPP } \\
\text { ( faliditas likuiditas } \\
\text { pembiayaan perumahan) }\end{array}$ & 116 & 0,15 \\
\hline S5 & $\begin{array}{l}\text { Tipe bangunan dengan } \\
\text { luas bangunan } 30 \mathrm{~m} 2 \\
(\text { diatas standar minimal } \\
21 \mathrm{~m} 2)\end{array}$ & 103 & 0,13 \\
\hline S6 & $\begin{array}{l}\text { Petak lahan dengan luas } \\
\text { tanah } 63 \mathrm{~m} 2 \\
(\text { diatas standar minimal } \\
60 \mathrm{~m} 2 \text { ) }\end{array}$ & 102 & 0,13 \\
\hline S7 & $\begin{array}{l}\text { Luas jalan fasum } \\
\text { perumahan } 7.5 \mathrm{~m} 2 \\
\text { (diatas standar minimal } 6 \\
\mathrm{~m} 2 \text { ) }\end{array}$ & 106 & 0,13 \\
\hline & Total Kekuatan & 799 & 1,00 \\
\hline Kode & Kelemahan & $\begin{array}{c}\text { Jumlah data } \\
\text { kuesioner }\end{array}$ & Bobot \\
\hline W1 & $\begin{array}{l}\text { Lokasi dekat dengan } \\
\text { pemakaman }\end{array}$ & 94 & 0,17 \\
\hline W2 & $\begin{array}{l}\text { Lokasi tidak berada di } \\
\text { Nol jalan } \\
\text { pengelolaan pemerintah }\end{array}$ & 89 & 0,17 \\
\hline W3 & $\begin{array}{l}\text { Lokasi lahan setara } \\
\text { dengan elevasi jalan }\end{array}$ & 91 & 0,17 \\
\hline W4 & $\begin{array}{l}\text { Mutu bahan usuk dari } \\
\text { kayu yang mudah } \\
\text { terbakar }\end{array}$ & 93 & 0,17 \\
\hline W5 & $\begin{array}{l}\text { Tidak ada dinding pagar } \\
\text { perumahan }\end{array}$ & 86 & 0,16 \\
\hline \multirow[t]{2}{*}{ W6 } & $\begin{array}{l}\text { Minimnya penerangan } \\
\text { pada akses } \\
\text { jalan masuk perumahan }\end{array}$ & 85 & 0,16 \\
\hline & Total Kelemahan & 538 & 1,00 \\
\hline
\end{tabular}

(Sumber: Hasil Analisis 2020)

Pada tabel 5 adalah pembobotan faktor internal dapat dihitung dengan cara jumlah data kuisioner adalah 121 dibagi dengan total jumlah data kuisioner sebesar 799 sebagai berikut $\frac{121}{799}=0,15$.

Tabel 6. Perhitungan Bobot Faktor Eksternal

\begin{tabular}{clcc}
\hline \multicolumn{3}{c}{ Bobot Faktor Eksternal } \\
\hline Kode & \multicolumn{1}{c}{ Peluang } & $\begin{array}{c}\text { Jumlah } \\
\text { data } \\
\text { kuesioner }\end{array}$ & Bobot \\
\hline O1 & $\begin{array}{l}\text { Permintaan penyediaan } \\
\text { perumahan } \\
\text { subsidi masih tinggi }\end{array}$ & 107 & 0,20 \\
\hline O2 & $\begin{array}{l}\text { Tingkat bunga KPR yang } \\
\text { rendah dan tetap }\end{array}$ & 120 & 0,22 \\
\hline
\end{tabular}

\begin{tabular}{clcc}
\hline O3 & Penyediaan lahan pemakaman & 104 & 0,19 \\
\hline O4 & $\begin{array}{l}\text { Tingkat daya beli masyarakat } \\
\text { perumahan bersubsidi }\end{array}$ & 100 & 0,19 \\
\hline O5 & $\begin{array}{l}\text { Adanya nilai tambah tiap tahun } \\
\text { terhadap harga jual lahan }\end{array}$ & 105 & 0,20 \\
\hline & \multicolumn{1}{c}{ Total Peluang } & 536 & 1,00 \\
\hline Kode & \multicolumn{1}{c}{ Ancaman } & $\begin{array}{c}\text { Jumlah } \\
\text { data } \\
\text { kuesioner }\end{array}$ & Bobot \\
\hline T1 & $\begin{array}{l}\text { Kenaikan harga jual perumahan } \\
\text { subsidi tiap tahun }\end{array}$ & 96 & 0,20 \\
\hline T2 & $\begin{array}{l}\text { Tidak ada bangunan komersil } \\
\text { dalam bentuk ruko }\end{array}$ & 95 & 0,20 \\
\hline T3 & $\begin{array}{l}\text { Banyaknya bermunculan } \\
\text { penyediaan } \\
\text { kavling dan perumahan non } \\
\text { subsidi }\end{array}$ & 101 & 0,21 \\
\hline T4 & $\begin{array}{l}\text { Adanya isu pencemaran } \\
\text { lingkungan }\end{array}$ & 90 & 0,19 \\
\hline T5 & $\begin{array}{l}\text { Kenaikan harga material dan } \\
\text { upah }\end{array}$ & 101 & 0,21 \\
\hline & $\quad$ Total Ancaman & 485 & 1,00 \\
\hline
\end{tabular}

(Sumber: Hasil Analisis 2020)

Pada tabel 6 adalah pembobotan dapat dihitung dengan cara jumlah data kuisioner adalah 107 dibagi dengan total jumlah data kuisioner sebesar 536 sebagai beikut $\frac{107}{536}=0,20$

\section{Matriks IFAS (Internal Factor Analysis Summary)}

Setelah faktor internal suatu perusahaan diidentifikasi suatu tabel IFAS (Internal Factor Analysis Summary) kemudian disusun untuk merumuskan faktor strategi internal dalam kerangka strength dan weakness perusahaan.

\section{Tabel 7. Matriks IFAS}

\begin{tabular}{|c|c|c|c|c|c|}
\hline \multicolumn{6}{|c|}{ IFAS } \\
\hline Kode & Kekuatan & Bobot & Rating & $\begin{array}{l}\text { Bob } \\
\text { ot X } \\
\text { Ratin } \\
\text { g) }\end{array}$ & $\begin{array}{l}\text { Skor } \\
\text { (S-W) }\end{array}$ \\
\hline S1 & $\begin{array}{l}\text { Produk } \\
\text { perumahan } \\
\text { Permata Alam } \\
\text { bersubsidi dengan } \\
\text { standart FLPP } \\
\text { ( faliditas } \\
\text { likuiditas } \\
\text { pembiayaan } \\
\text { perumahan) }\end{array}$ & 0,15 & 3 & 0,45 & 1 \\
\hline S2 & $\begin{array}{l}\text { Lokasi dekat } \\
\text { dengan pasar } \\
\text { tradisional }\end{array}$ & 0,16 & 3 & 0,47 & \\
\hline
\end{tabular}

Proteksi/Juni 2021 Volume 3 No. 1 


\begin{tabular}{|c|c|c|c|c|}
\hline & $\begin{array}{l}\text { kurang lebih } 1,3 \\
\text { km }\end{array}$ & & & \\
\hline S3 & $\begin{array}{l}\text { Lokasi dekat } \\
\text { dengan yayasan } \\
\text { pendidikan } \\
\text { (Pondok Pesantren } \\
\text { dan Sekolah) } \\
\end{array}$ & 0,16 & 4 & 0,64 \\
\hline S4 & $\begin{array}{l}\text { Bangunan layak } \\
\text { huni dengan } \\
\text { standar FLPP } \\
\text { ( faliditas } \\
\text { likuiditas } \\
\text { pembiayaan } \\
\text { perumahan) }\end{array}$ & 0,15 & 4 & 0,58 \\
\hline S5 & $\begin{array}{l}\text { Tipe bangunan } \\
\text { dengan luas } \\
\text { bangunan } 30 \mathrm{~m} 2 \\
\text { (diatas standar } \\
\text { minimal } 21 \mathrm{~m} 2 \text { ) }\end{array}$ & 0,13 & 3 & 0,39 \\
\hline S6 & $\begin{array}{l}\text { Petak lahan } \\
\text { dengan luas tanah } \\
63 \mathrm{~m} 2 \\
(\text { diatas standar } \\
\text { minimal } 60 \mathrm{~m} 2 \text { ) }\end{array}$ & 0,13 & 3 & 0,38 \\
\hline S7 & $\begin{array}{l}\text { Luas jalan fasum } \\
\text { perumahan } 7.5 \mathrm{~m} 2 \\
\text { (diatas standar } \\
\text { minimal } 6 \mathrm{~m} 2 \text { ) }\end{array}$ & 0,13 & 3 & 0,40 \\
\hline \multicolumn{2}{|r|}{ Total Kekuatan } & 1,00 & & 3,30 \\
\hline Kode & Kelemahan & $\begin{array}{c}\text { Bobo } \\
t\end{array}$ & Rating & $\begin{array}{l}\text { (Bob } \\
\text { ot x } \\
\text { Ratin } \\
\text { g) }\end{array}$ \\
\hline W1 & $\begin{array}{l}\text { Lokasi dekat } \\
\text { dengan } \\
\text { pemakaman } \\
\end{array}$ & 0,17 & 2 & 0,34 \\
\hline W2 & $\begin{array}{l}\text { Lokasi tidak } \\
\text { berada di Nol } \\
\text { jalan } \\
\text { pengelolaan } \\
\text { pemerintah }\end{array}$ & 0,17 & 2 & 0,34 \\
\hline W3 & $\begin{array}{l}\text { Lokasi lahan } \\
\text { setara dengan } \\
\text { elevasi jalan }\end{array}$ & 0,17 & 2 & 0,34 \\
\hline W4 & $\begin{array}{l}\text { Mutu bahan usuk } \\
\text { dari kayu yang } \\
\text { mudah terbakar }\end{array}$ & 0,17 & 3 & 0,51 \\
\hline W5 & $\begin{array}{l}\text { Tidak ada dinding } \\
\text { pagar perumahan }\end{array}$ & 0,16 & 2 & 0,32 \\
\hline W6 & $\begin{array}{l}\text { Minimnya } \\
\text { penerangan pada } \\
\text { akses } \\
\text { jalan masuk } \\
\text { perumahan }\end{array}$ & 0,16 & 2 & 0,32 \\
\hline
\end{tabular}

(Sumber: Hasil Analisis 2020)

Berdasarkan tabel 7 diketahui bahwa faktor internal pada kekuatan adalah 3.30 dan pada kelemahan 2.17 jadi total faktor IFAS 5,47, kemudian dicari skornya dengan selisih S-W mendapatkan nilai 1. Menghasilkan nilai signifikasi dari bobot terbesar kekuatan yaitu Lokasi dekat dengan yayasan pendidikan (Pondok Pesantren dan Sekolah) untuk ancaman Mutu bahan usuk dari kayu yang mudah terbakar. Hal ini menandakan bahwa perumahan permata alam memiliki strategi pemasaran pada perencanaan internalnya.

\section{Matriks EFAS (Eksternal Factor Analysis Summary)}

Setelah faktor internal suatu perusahaan diidentifikasi suatu tabel EFAS (Eksternal Factor Analysis Summary) disusun untuk merumuskan faktor strategi eksternal dalam kerangka opportunity dan threats perusahaan.

Tabel 8. Matriks EFAS

\begin{tabular}{|c|c|c|c|c|c|}
\hline \multicolumn{6}{|c|}{ EFAS } \\
\hline Kode & Peluang & Bobot & Rating & $\begin{array}{l}\text { (Bobot } \\
x \\
\text { Rating) }\end{array}$ & $\begin{array}{l}\text { Skor } \\
(\mathrm{O}-\mathrm{T})\end{array}$ \\
\hline O1 & $\begin{array}{l}\text { Permintaan } \\
\text { penyediaan } \\
\text { perumahan } \\
\text { subsidi } \\
\text { masih tinggi }\end{array}$ & 0,20 & 3 & 0,60 & \\
\hline $\mathrm{O} 2$ & $\begin{array}{l}\text { Tingkat } \\
\text { bunga KPR } \\
\text { yang rendah } \\
\text { dan tetap }\end{array}$ & 0,22 & 4 & 0,88 & \\
\hline $\mathrm{O} 3$ & $\begin{array}{l}\text { Penyediaan } \\
\text { lahan } \\
\text { pemakaman }\end{array}$ & 0,19 & 3 & 0,57 & \\
\hline $\mathrm{O} 4$ & $\begin{array}{l}\text { Tingkat } \\
\text { daya beli } \\
\text { masyarakat } \\
\text { perumahan } \\
\text { bersubsidi }\end{array}$ & 0,19 & 3 & 0,57 & \\
\hline O5 & $\begin{array}{l}\text { Adanya nilai } \\
\text { tambah tiap } \\
\text { tahun } \\
\text { terhadap } \\
\text { harga jual } \\
\text { lahan }\end{array}$ & 0,20 & 3 & 0,60 & 0,40 \\
\hline & 1 Peluang & 1,00 & & 3,21 & \\
\hline Kode & Ancaman & Bobot & Rating & $\begin{array}{c}\text { (Bobot } \\
\mathrm{x} \\
\text { Rating) }\end{array}$ & \\
\hline $\mathrm{T} 1$ & $\begin{array}{l}\text { Kenaikan } \\
\text { harga jual } \\
\text { perumahan } \\
\text { subsidi tiap } \\
\text { tahun }\end{array}$ & 0,20 & 3 & 0,60 & \\
\hline $\mathrm{T} 2$ & $\begin{array}{l}\text { Tidak ada } \\
\text { bangunan }\end{array}$ & 0,20 & 3 & 0,60 & \\
\hline
\end{tabular}

Proteksi/Juni 2021 Volume 3 No. 1 


\begin{tabular}{|c|c|c|c|c|}
\hline & $\begin{array}{l}\text { komersil } \\
\text { dalam } \\
\text { bentuk ruko }\end{array}$ & & & \\
\hline $\mathrm{T} 3$ & $\begin{array}{l}\text { Banyaknya } \\
\text { bermuncula } \\
\mathrm{n} \\
\text { penyediaan } \\
\text { kavling dan } \\
\text { perumahan } \\
\text { non subsidi }\end{array}$ & 0,21 & 3 & 0,63 \\
\hline $\mathrm{T} 4$ & $\begin{array}{l}\text { Adanya isu } \\
\text { pencemaran } \\
\text { lingkungan }\end{array}$ & 0,18 & 2 & 0,38 \\
\hline T5 & $\begin{array}{l}\text { Kenaikan } \\
\text { harga } \\
\text { material dan } \\
\text { upah }\end{array}$ & 0,21 & 3 & 0,60 \\
\hline \multicolumn{2}{|c|}{ Total Ancaman } & 1,00 & & 2,81 \\
\hline
\end{tabular}

(Sumber: Hasil Analisis 2020)

Berdasarkan pada tabel 8 diketahui bahwa faktor eksternal pada peluang memiliki total 3.21 dan pada ancaman 2.81 jadi total faktor EFAS 6,02, kemudian dicari skornya dengan selisih O-T mendapatkan nilai 0,40. Menghasilkan nilai signifikasi dari bobot terbesar peluang yaitu tingkat bunga yang rendah dan tetap untuk ancaman banyaknya bermunculan penyediaan kavling dan perumahan non subsidi.

Hal ini menandakan bahwa perumahan permata alam memiliki strategi pemasaran pada perencanaan faktor eksternalnya.

\section{Diagram Layang Analisis SWOT}

Dari hasil perhitungan pada faktor-faktor tersebut maka dapat digambarkan dalam diagram layang SWOT, menjelaskan masing-masing nilai skor terhadap analisis SWOT. Berikut adalah gambar diagram layang:

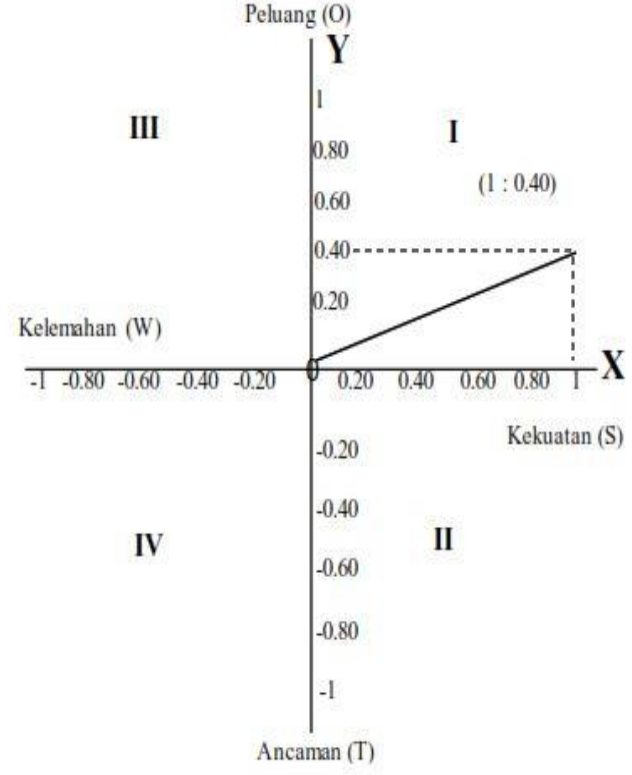

Gambar 2. Diagram Layang SWOT

(Sumber: Hasil Analisis 2020)

Pada gambar diagram layang terletak pada kuadrat $1(1: 0,40)$.

Menunjukan strategi agresif (positif-positif) jadi memungkinkan untuk tetap dilakukannya kegiatan yang dapat menguntungkan perusahaan tersebut.

\section{Matriks SWOT}

Matriks SWOT merupakan alat yang dipakai untuk mengukur faktor strategi perusahaan. Matriks ini dapat menghasilkan empat sel alternatif strategi yang dapat dilihat pada tabel dibawah ini: 
Tabel 9. Matriks SWOT

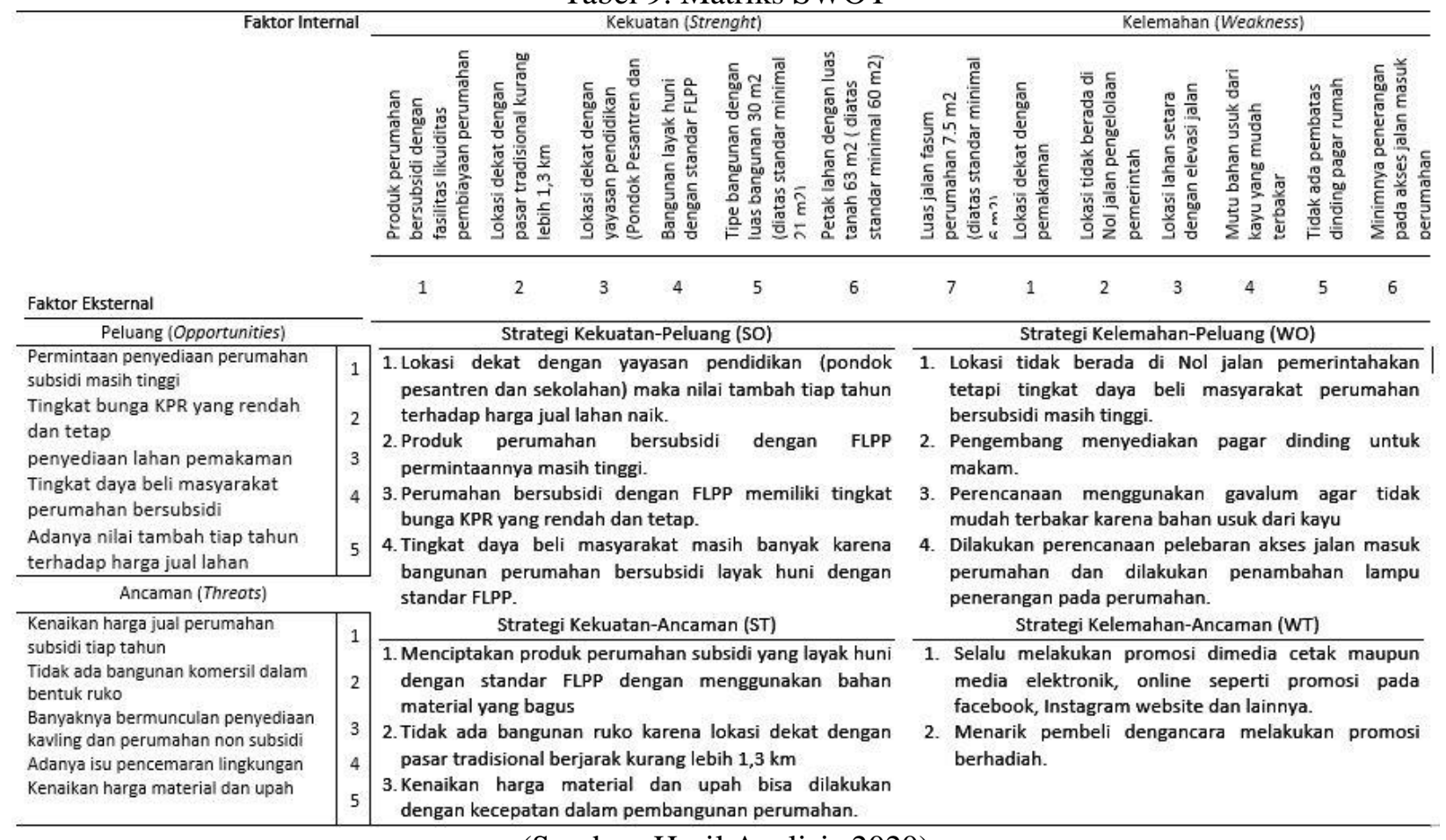

(Sumber: Hasil Analisis 2020)

Berdasarkan analisis diatas menunjukkan bahwa strategi pemasaran dapat ditentukan oleh kombinasi faktor internal dan faktor eksternal.

\section{KESIMPULAN}

Hasil nilai matriks IFAS (Internal Factor Analysis Summary) total 5,47 dan hasil nilai matriks EFAS (Eksternal Factor Analysis Summary) denga total 6,02, kemudian dicari total skor dari faktor internal yaitu 1 dan hasil skor dari faktor eksternal adalah 0,40. Kemudian dijadikan diagram layang kuadrant 1 dengan hasil strategi agresif (positif-positif) yaitu pembangunan proyek perumahan subsidi bisa dilakukan dengan hasil yang menguntungkan.

\section{REFERENSI}

Arlinah and Khadijah. 2017."Metode SWOT Dalam Perencanaan Pengembangan Pemukiman Tepi Air Berbasis Pengetahuan Lokal Dan Partisipatif Di Desa Daruba Kabupaten Morotai," J.ETNOHISTORI2

Frederika, A. A. Wiranata, And I. B. G. A. P. Kamajaya. 2016. "Analisis Investasi
Pembangunan Dedari Kenderan Villas," J. Ilm. Tek. Sipil, Vol. 20, No. 2, Pp. 127-133, 2016, [Online].

Prasetyo, Agung dkk. 2020. "kajian awal perencanaan lajur khusus sepeda dengan menggunakan metode IPA (Importance Performance Analysis) dan SWOT"

Sudipta, Ketut Gusti I Gede. 2018. "Analisis Kelayakan Proyek Pembangunan Perumahan Di Kabupaten Jembrana," Fakultas Teknik Universitas udayana.

Veranda Usman, Yulita and Wiwi Yaren. 2013. "Analisa Strategi Pemasaran Perumahan Bekasi Timur Regensi 3" Fakultas Teknik, Universitas Pancasila Yanto, Hari dkk. 2019. " Analisis Investasi Pada Pembangunan Perumahan Nuansa Beringin" Jurnal Teknik Sipil, Fakultas Teknik, Universitas Lancang Kuning Pekanbaru 